6. Здравомыслов А.Г. Потребности. Интересы. Ценности. М.: Политиздат, 1986. 221 с.

7. Якунин В.Я. Педагогическая психомогия: учеб. пособие. 2-е изд. СПб.: Изд-во Михайлова В. А., 2000. 349 c.

\title{
References
}

1. Kagan, M.S. (1997). Philosophical theory of values. St. Petersburg: Petropolis. 205 p.

2. Saleev, V.A. (2000). The Concept of aesthetic education of children and youth of the Republic of Belarus. Fundamentals of arts. 4. 8-30.

3. Abramov A.L. et al. (1989). Aesthetics: dictionary. In A.A. Belyaeva (Ed.). Moscow: Politizdat. 445 p.

\section{STATKEVICH Elena,}

teacher of the Pinsk Industrial Pedagogical College, Brest State Technical University, Republic of Belarus e-mail: CNFNRTDBX@yandex.by

\section{ESSENTIAL CHARACTERISTICS OF AESTHETIC VALUES OF HIGH SCHOOL STUDENTS}

Abstract. The article substantiates the category of aesthetic values as an important component of the educational process, it is noted that values play a significant role in the formation of creative personality, among which a special place is occupied by aesthetic values. The study of aesthetic values is based on the normative documents of the Republic of Belarus. On the basis of a systematic analysis of the structural components of aesthetic values of school students.

In accordance with the selected structure of aesthetic values, the pedagogical influence on the structure of such values is assessed. It manifests itself in the accumulation of knowledge, ideas; stimulating the experience of the values of beauty, harmony, aesthetic ideal; enriching the experience of the aesthetic activities of high school students in accordance with the values of beauty, harmony and aesthetic ideal. At the same time, the choice of logic and tools for their formation is carried out taking into account the intrapersonal mechanism of axiological development with the priority updating of the aesthetic experience of high school students. This mechanism can be represented by the following chain of intrapersonal activity: aesthetic perception $\rightarrow$ aesthetic experience $\rightarrow$ assessment-thinking $\rightarrow$ creative expression $\rightarrow$ axiological reflection.

Keywords: aesthetic values; aesthetic education; competences; structure; components of aesthetic value of schoolchildren; specific forms and features of aesthetic value.

Одержано редакиією 14.10.2018 Прийнято до публікаиї̈ 19.10.2018

DOI 10.31651/2524-2660-2018-17-62-66

ORCID 0000-0003-1448-4643

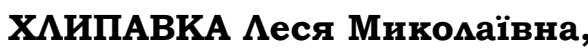

аспірантка кафедри педагогіки вищої школи та освітнього менеджменту,

Черкаський національний університет імені Богдана Хмельницького e-mail: lesya.khlipavka@gmail.com

Удк 378

\section{ПІДГОТОВКА МАЙБУТНЬОГО ВЧИТЕАЯ ІСТОРЇ̈ ДО ВИКААДАННЯ ЄДИНОГО (ІНТЕГРОВАНОГО) КУРСУ ІСТОРІї}

у статті розглянуто проблеми професійної підготовки вчителів історії до викладання інтегрованих курсів із історії для старшої школи, визначено завдання й иілі інтеграиії з проекиією на фахову підготовку.

Ключові слова: професійна підготовка; навчальна програма дисиипліни; єдиний курс icmopiï.

Постановка пробцеми. Формування громадянського суспільства, продовження демократичних реформ, інтеграція України в світовий і європейський простори значною мірою залежить від історичної освіти, яка не може існувати ізоцьовано від завдань, що стоять перед суспільством.
Сучасна дидактика історії не може зігнорувати вимог глобалізації. Цілком об'єктивною основою сучасного світу $\epsilon$ єдність, яка виявляється у взаємозалежностях між народами, державами, регіонами. Важливо, що ця єдність може бути відкрита й відчута мюдиною. Історична наука та освіта, аби набути сенсу в глобальному світі, має стати своєрідною грою між деталями і абстрактним розумуванням. Це останнє не можна досягнути без ширшого контексту. Суть вцасного національного можна збагнути тільки через відношення із зовнішнім світом. Як засвідчує сучасна світова практика, 3 виникненням постіндустріального суспімьства нації та націонамьні держави не 
зникають, вони продовжують залишатися активними гравцями на історичній сцені, надаючи матеріал для реалізації тенденцій модернізації, демократизації тощо.

Впровадження єдиного курсу історії для старшої школи - мише перший крок до отримання в сучасній Україні нової якості національної історичної свідомості. Єдиний курс дозволяє позбутися в його межах непотрібної інформації енциклопедичного характеру, натомість поряд 3 політичними увести соціальні й культурологічні характеристики; покласти в основу єдиного курсу історії методомогічний $і$ концептуальний принцип "україноцентризму". Мета загальної історичної освіти - національна самоідентифікація української молоді та раціоналізація її історичного мислення. Реалізація означених питань вимагає підвищення ефективності професійної підготовки майбутніх учителів історії через трансформацію української освітньої системи.

Мета статті. Аналіз процесу підготовки (формування готовності) майбутнього вчителя до викладання єдиного (інтегрованого) курсу історії, який може стати у нагоді в сучасних умовах моде-

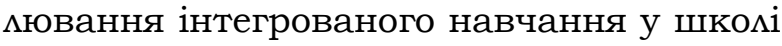
на сучасному етапі.

Викцад основного матеріалу дослідження. Аналіз теоретичного доробку засвідчує зацікавленість вітчизняних науковців до проблеми професійної підготовки майбутніх вчителів історії. Дослідження зосереджувались у кількох напрямках:

- фахова підготовка (А. Булда,

Т. Гроховська, I. Єрмакова,

В. Майборода, Т. Муномарова,

С. Нікітчина, А. Старєва);

- підготовка до інноваиійної

діяльності (Т. Скрябіна, О. Смірнова);

- методична підготовка (А. Вагін, П. Гора, Н. Дайрі, С. Єжова, А. Нікора, О. Пометун).

Дослідник А. Булда розглядаючи проблему майбутніх вчителів історії осмислює іiі як процес формування вмінь і навичок, які необхідні для набуття професійних характеристик у галузі викладання гуманітарних предметів (історія, українознавство, суспіньствознавство, правознавство), робить акцент на єдності та співвідношенні теоретичної та практичної підготовки, де на другий план відходять питання ідеології та політики [1, с. 2-29].

Т. Гроховська зауважує, що фахова підготовка майбутніх вчителів історії передбачає оволодіння студентами комплексом спеціальних знань предметнофахового циклу та має бути спрямована на поглиблення й інтеграцію загальнофілософських, психолого-педагогічних і спеціальних історичних знань; створення спеціальних умов для формування фахівця широкого гуманітарного профілю [2, с. 8-9].

Досліджуючи процес підготовки майбутніх учителів історії В. Снагощенко зазначає, що діяльність вчителя історії $\epsilon$ багатоаспектною та поліфункціональною за своїм змістом та потребує залучення якісно нових ресурсів у процес його фахової підготовки [3, с. 2-9].

Проблему підготовки майбутніх вчителів історії до інноваційної діяльності розглядала О. Смірнова, яка вбачала його вирішення на загальнопедагогічному та фаховому рівнях. Дослідниця вказала на необхідності опанування студентами загальнопедагогічних дисциплін ("Педагогіка", "Історія педагогіки", "Педагогіка вищої і загальноосвітньої школи»), а також "Шкільний курс "Історія України" та методика його викладання", спецкурсів за вибором ("Нові педагогічні технології", "Сучасний урок: панорама методичних ідей" тощо). Наголос О. Смірнова зробила на тому, що мише органічна єдність усіх методів навчання надає навчальному процесу необхідної універсальності й продуктивності, робить його проблемним за змістом та ефективним за формою [4, c. 51-52].

Натомість ще й досі відсутні дослідження питання підготовки вчителів до викладання єдиного (інтегрованого) курсу історії. Єдиний курс історії дозво$\Lambda я є$ вирішити проблему, що існує завдяки поділу на історію України та всесвітню історію - проблему фрагментарності історичного світогляду учнів, відсутність навіть шансу на узагальнення багатого історичного матеріалу, а через це й обмеженості творчого потенціалу предмета. Вивчення історії України через протиставлення світові, по суті, перетворилося 3 дійового засобу формування українського патріотизму та української національної ідентичності на свою протилежність. Адже навряд чи в сучасному відкритому і взаємозалежному світі 
можна зберегти себе без постійного порівняння з оточенням. Особливого переосмислення потребує історія XX століття - у світАі того, Як сили глобалізації вплинули на національні спільноти й держави, і навпаки.

Ідея єдиного курсу історії дискутувамася в науковому та вчительському середовищах останні два десятиліття. Першою спробою ï систематизувати та узагальнити стали напрацювання Концепції єдиного курсу історії в 12 річній школі: " $\Lambda$ ьвівська ініціатива". В основі вивчення історії було покладено 3 блоки: пропедевтичний курс «Історія та основи знань про суспільство" (5-6), інформаційноосмислювальний (елементарний) курс (79), тематичні навчальні цілі (10-12) кла- си. Але реалізувати вищезгадану концепцію не вдалося [5, с. 5-7].

У 2017 році Міністерство освіти i науки України створимо робочу групу дмя оновлення шкільних програм із історії, результатами іï роботи стало укмадання програми інтегрованого курсу «Історія: Україна і світ" для 10-11 класів. Дия ознайоммення із концепцією програми єдиного курсу до прикладу у 11 класі ми пропонуємо розглянути декімька типів мікромодулів змісту загальної історичної освіти, які описані водночас як інформаційні питання змісту та як система знань-відомостей, осмислених знань (розумінь) і знань-процедур мислиннєвої діяльності (умінь), що мають бути результатом учіння.

\begin{tabular}{|c|c|}
\hline \multicolumn{2}{|c|}{ РоздіА 2. СВІТ У ПОШУКАХ НОВИХ МОДЕАЕЙ РОЗВИТКУ } \\
\hline $\begin{array}{c}\text { Очікувані резумьтати навчамьно-пізна } \\
\text { діямьності }\end{array}$ & Зміст навчамьного матеріалу \\
\hline 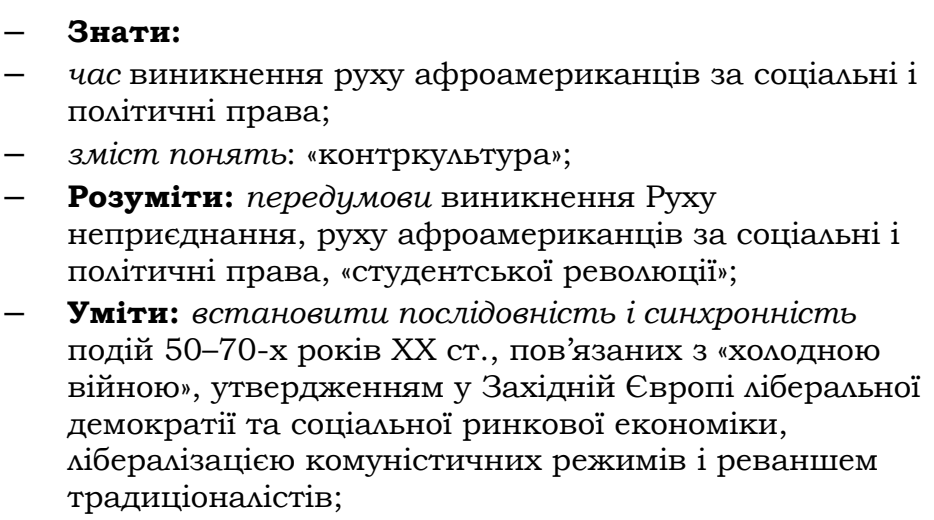 & $\begin{array}{l}\text { Демократичні рухи в Західній } \\
\text { Європі та США в 1960-1970-х роках. } \\
\text { Прояви неполітичного протесту. } \\
\text { Молодіжні виступи кінця 1960-х рр.: } \\
\text { причини, прояви, наслідки. } \\
\text { Ювеналізація, і зародження контр- } \\
\text { культури. Рок-культура. } \\
\text { Рух афроамериканців за соціальні та } \\
\text { політичні права. Мартин Аютер Кінг. }\end{array}$ \\
\hline \multicolumn{2}{|c|}{$\begin{array}{l}\text { Молодіжні рухи і рок-культура як соціальне явище 1960-1970-х рр.; } \\
\text { Конфлікт мюдини і системи: поширення явищ контркультури в СРСР; }\end{array}$} \\
\hline \multicolumn{2}{|c|}{ РоздіА 4. ФОРМУВАННЯ ПОСТІНДУСТРІААЬНОГО СУСПІАЬСТВА } \\
\hline $\begin{array}{l}\text { Знати: } \\
-\quad \text { час початку та етапи НТР, «зеленої" й інформаційної } \\
\text { революцій, } \\
-\quad \text { внесок українців у науково-технічну революцію; } \\
-\quad \text { зміст понять: "інновації", "постіндустріальне } \\
\text { (інформаційне) суспільство", "науково-технічна } \\
\text { революція (НТР)", "зелена революція", «інформаційна } \\
\text { революція", "Транснаціональна корпорація (ТНК)". } \\
\text { Розуміти: } \\
\text { - вплив НТР, "зеленої» та інформаційної революцій на } \\
\text { економіку та суспільство; } \\
\text { Уміти: }\end{array}$ & $\begin{array}{l}\text { Науково-технічна ревомюція. } \\
\text { НТР: ознаки, етапи та напрями. } \\
\text { Роль науково-дослідних центрів: } \\
\text { Кремнієва долина в США. Стівен } \\
\text { Джобс і Стівен Возняк. } \\
\text { "Зелена" та інформаційна революції. } \\
\text { Посилення "вертикальної" та "горизон- } \\
\text { тальної» інтеграції. } \\
\text { Транснаціональні корпорації. } \\
\text { Випереджуючий розвиток невиробни- } \\
\text { чої сфери. } \\
\text { Зміни у змісті та характері праці. }\end{array}$ \\
\hline Оріснтовні теми дия навчапь & IX проектів: \\
\hline
\end{tabular}


Такий підхід покликаний сприяти глибшому розумінню школярами таких складних компонентів історичного пізнання як: причини й наслідки, мінливість і безперервність, прогрес і регрес, багаточинниковість, нелінійність, системність, а також усвідомленню ними невичерпності пізнання, убезпеченню від поспішних узагальнень та від ілюзії абсо$\Lambda$ ютного знання.

Вищенаведений фрагмент укладання шкільної програми єдиного курсу історії вимагає переосмислення й питання підготовки вчителів історії. У статті 1 Закону України "Про вищу освіту" задекларована академічна свобода - самостійність і незалежність учасників освітнього процесу під час провадження педагогічної, науково-педагогічної, наукової та/або інноваційної діяльності, що здійснюється на принципах свободи слова і творчості, поширення знань та інформації, проведення наукових досліджень і використання іх результатів з урахуванням обмежень, встановцених законом [6, с. 2]. Це дає можливість вищим навчальним закладам самостійно укладати навчальні плани дмя підготовки фахівців.

На основі вивчення навчальних планів та програм підготовки фахівців за спеціальністю 014.03 Середня освіта (Iсторія) у Аьвівському національному університеті імені Івана Франка та Черкаському національному університеті імені Богдана Хмельницького зауважимо, що навчальні курси поділяються на загальні, фахові та спеціальні та курси за вибором, проте фахові та спеціальні більшою мірою належать до класичних програм в яких увага зосереджена винятково на інформаційному наповненні здебільшого фрагментарного характеру, а в їх основі покладено політичну історію, що концентрується на "подієвих" аспектах минулого та унеможливлює дия студента поєднання національної й зарубіжної історії в гармонійне ціме.

Дия студентів 1-3 курсів історичного факультету відповідно до навчальних планів передбачено вивчення курсів ${ }^{3}$ :

- загальні - Українська мова; Іноземна мова; Філософія;

- фрахові - Вступ до історії та педагогічної професії; Педагогіка; Історія

\footnotetext{
Навчальні курси вказані відповідно до Навчального плану дия студентів I-III курсів історичного факультету $\Lambda$ НУ ім. Івана Франка (OC "бакалавр") денної форми навчання.
}

стародавніх цивімізації; Історія середніх віків XII-XV ст.; Історія України пізнього середньовіччя i ранньомодерного часу; Історія Західної Європи та Америки XIX початку XX ст.;

- спеціальні - Загальна етнологія; Культурна антропологія; Етнологія України.-

- за вибором - Економічна історія України; Світ розваг середньовічної мюдини; Соціологія змочинності; Мова, громадська думка і пропаганда; Етнічні стереотипи українців; Історичні пам'ятки Галичини; Соціальна та політична історія

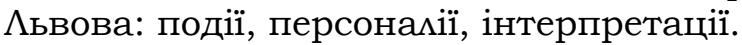

Подібна вузівська традиція мекцій та семінарських занять створює у студентів мише загальне уявлення про історичне минуле. Те, як ми розуміємо історію, свідчить про наше бачення світу в цікому, про усвідомкення завдань, які треба розв'язувати в осяжному майбутньому. Шкільну дидактику історії в сучасній Україні можна порівняти з фізичним образом світу, що побудований на ньютонівській атомарній моделі. Згідно з нею, будь-яке ціле можна розкласти на дрібні неподільні частини, докладне знання яких дасть вичерпну інформацію про предмет загалом. Насправді, це уявлення вже давно застаріло, воно не відповідає ні актуальній філософській, ні фізичній картині світу. У ньому не враховано, що не тільки вмастивості частин впливають вцастивості цілого, а й навпаки - ціле визначає властивості частин. Останнім часом інтерес студентів до семінарських занять значно знизився, що має стиму^ювати викладачів шукати нові методи та підходи до формування готовності майбутніх учителів історії до викладання єдиного курсу історіі.

Висновки i перспективи подацьших досліджень. Підготовка майбутнього вчителя до викладання єдиного курсу історії здійснюється на рівні створення спецкурсів та міждисциплінарної взаємодії у вивченні окремих дисциплін. Перспективу подальших досліджень убачаємо в розробленні концептуальних засад створення навчальних програм для підготовки майбутніх вчителів до викладання єдиного курсу історії в школі 3 урахуванням принципу інтеграції навчання та формування компетентностей фахівця необхідних в умовах сучасного соціокультурного освітнього простору. 


\section{Список бібціографічних посицань}

1. Булда А.А. Теоретичні основи практичної підготовки вчителів історії в педагогічних навчальних закладах України (історикопедагогічний аспект): автореф. дис. ... д-ра пед. наук: спец: 13.00.02 "Теорія та методика навчання історії". Київ, 2009. 36 с.

2. Горохівська Т. М. Формування світоглядної культури майбутніх учителів у процесі фахової підготовки: автореф. дис. ... канд. пед. наук: спец. 13.00.04 «Теорія та методика професійної освіти". Вінниця, 2009. 24 c.

3. Снагощенко В.В. Професійна підготовка майбутнього вчителя історії засобами музейної педагогіки : автореф. дис. ... канд. пед. наук: спец: 13.00.04 «Теорія і методика професійної освіти". Київ, 2010. 22 с.

4. Смірнова О.О. Методичні аспекти підготовки майбутніх учителів історії до інноваційної педагогічної діяльності. Рідна школа, 2010. № 11 (Аистопад). С. 50-53.

5. Вінніченко О.О., Мудрий М.М, Пастушенко Р.Я., Сирота Р.О. Концепції єдиного курсу історії в 12 річній школі: " $\Lambda$ ьівська ініціатива". Аьвів, 2004. 213 с.

6. Про вищу освіту: Закон України від 01.07.2014 №1556-VII. URL: http://zakon.rada.gov.ua/laws/show/155618.

\section{References}

1. Bulda, A.A. (2009). Theoretical bases of practical training of teachers of history in pedagogical educational institutions of Ukraine (historical and pedagogical aspect) (Doctor Sciences Dissertation ) Thesis. Kyiv. 36 p.

2. Gorokhivska, T.M. (2009). Formation of worldview culture of future teachers in the process of professional training. (Ph.D Dissertation ) Thesis.Vinnitsa, 2009. 24 p.

3. Snagoschenko, V.V. (2010). Professional training of the future teacher of history by means of museum pedagogy (Ph.D Dissertation ) Thesis. Kyiv, 2010.22 p.

4. Smirnova, O.O. (2010). Methodical aspects of preparing future teachers of history for innovative pedagogical activity. Native school. 11 (November). 50-53.

5. Vinnichenko, O., Mudrij, M.M., Pastushenko, R.Ya., Syrota, R.O. (2004). Concepts of the only course of history in the 12 year school: "Lviv Initiative". Lviv. 213 p.

6. About vyshu osvitu: Law of Ukraine 01.07.2014 №1556-VII. Retrieved from http:/ /zakon.rada.gov.ua/laws/show/155618.

\section{KHLYPAVKA Lesia,}

Postgraduate Student of Higher School Pedagogy and Educational Management Department, Bohdan Khmenlnytsky National University at Cherkasy

e-mail: lesya.khlipavka@gmail.com

\section{TRAINING OF A FUTURE HISTORY TEACHER TO TEACHING A UNIFIED (INTEGRATED) \\ COURSE IN HISTORY}

Abstract. The article analyzes the need to prepare the future teacher for teaching in a school a single (integrated) course of history. The peculiarities and disadvantages of the training of future teachers of history are highlighted.

Introduction. The introduction of a single course of history for senior high schools is only the first step towards obtaining in the modern Ukraine a new quality of national historical consciousness. The only course allows you to get rid of unnecessary information in its encyclopedic character within its limits; instead, along with the political ones, enter social and cultural characteristics; to lay the basis for a unified course of history methodological and conceptual principle of "Ukrainocentrism". The purpose of the general historical education is the national self-identification of Ukrainian youth and the rationalization of its historical thinking.

The implementation of these issues requires increasing the efficiency of the training of future teachers of history through the transformation of the Ukrainian educational system. Therefore, there is a need to analyze the current state of the current state of the abovementioned issue in the practice of pedagogical universities, which will reveal the problems and determine the perspective ways of their solution in the educational process.

Results. On the basis of the study of curricula and programs of training specialists in the specialty 014.03 Secondary Education (History) at the Ivan Franko National University of Lviv and note that the training courses are divided into general, professional and special and elective courses, however, professional and special ones belong to a greater extent classical programs in which attention is focused exclusively on informational content of a largely fragmentary nature, and is based on a political history that focuses on "event" aspects of the past and makes it impossible for the student to combine national and foreign history into a harmonious whole.

A similar university tradition of lectures and seminars creates a general idea of the historical past. The way we understand history, shows our vision of the world as a whole, the awareness of the tasks that need to be solved in the foreseeable future. Recently, the interest of students in seminars has significantly decreased, which should encourage teachers to seek new methods and approaches to shaping the readiness of future teachers of history to teach a unified course of history.

Conclusion. Thus, the analysis of the problem proves that the problem under investigation is relevant, has theoretical and practical significance. The obtained data allow us to conclude that in university practice the training of future teachers for the teaching of a single course of history is carried out at the level of creating special courses and interdisciplinary interaction in the study of individual disciplines. The prospect of further research is seen in the development of the conceptual framework for the creation of training programs for the training of future teachers to teach a unified course of history at school, taking into account the principle of integration of learning and the formation of the competence of a specialist in the conditions of contemporary socio-cultural educational space.

Keywords: the only course of history; professional training; curriculum of discipline. 